Witold SADOWSKI

Uniwersytet Warszawski

\title{
Wizualizacja litanii w poezji konkretnej: Gomringer, Jandl, Bocian
}

Na temat przewodni artykułu poświęconego relacjom intersemiotycznym litania została wybrana $\mathrm{z}$ dwóch powodów. Po pierwsze dlatego, że w swojej historii, liczącej co najmniej pięć tysięcy lat, gatunek ten przeszedł od etapu synkretyzmu sztuk do etapu ich rozpadu na niezależne systemy. Po drugie zaś z tej przyczyny, że jeszcze przed owym rozpadem wykształcił on swój własny obraz świata, komunikowany w każdym utworze mającym strukturę litanii.

Pojęcie synkretyzmu nawiązuje do koncepcji Aleksandra Wiesiołowskiego (Wiesiołowski 1913: 390-391), który ponad sto lat temu zwrócił uwagę na intrygujące zjawisko: sztuki traktowane kiedyś jako nierozerwalna całość (jak na przykład dramat i teatr czy poezja i recytacja) są dzisiaj postrzegane osobno. W rozwoju kultury na przestrzeni tysiącleci zachodzi zatem zjawisko, które w aktualnych kategoriach semiotycznych można opisywać analogicznie do ewolucyjnego różnicowania się języków: przekodowanie realizowane w naszych czasach jako relacja międzysystemowa (cudza wypowiedź jest na tyle inna od mojej, że w procesie rozumienia muszę ją przełożyć z jednego języka na drugi) miało przed wiekami charakter wewnątrzsystemowy (cudzą wypowiedź można było zrozumieć w ramach tego samego języka).

Litania, której historia, jak już wspomniano, liczy sobie co najmniej pięć tysięcy lat, stanowiła pierwotnie zintegrowane wydarzenie poetycko-muzyczno-liturgiczne, rozgrywające się w ramach architektonicznie określonej prze- 
strzeni miejskiej, oparte na spójnych założeniach teologiczno-kosmologicznych eksponowanych przez hierarchię społeczną tłumu idącego w procesji oraz mające bezpośrednie paralele w przedstawieniach malarskich i rzeźbiarskich. $\mathrm{Z}$ czasem jednak ta synkretyczna wspólnota uległa rozproszeniu, oddając swoje komponenty samodzielnie rozwijającym się nurtom: przede wszystkim modlitwie kościelnej (która zachowała gatunkowy schematyzm litanii), poezji (wykorzystującej aspekty wersyfikacyjne konwencji) oraz twórczości wielkich kompozytorów (gdzie najsilniej dochodzi do głosu, przy zachowaniu różnic wynikających z odmiennych etapów historii muzyki, chóralny czy multifoniczny ${ }^{1}$ wymiar społecznego aktu litanii) ${ }^{2}$.

Litania pozwala więc na zadawanie analogicznych pytań jak te podejmowane przez lingwistów. W jakich warunkach relacje wewnątrzsystemowe przeistaczają się w zewnątrzystemowe? Jakie konsekwencje dla odbioru dzieł powstających w ramach każdego z nurtów ma ów zasadniczy fakt, że ta semiotyczna transformacja dotyczy w swoim podstawowym zakresie nie repertuaru litanijnych komponentów, lecz systemowych ram rzutujących na typ relacji między owymi komponentami?

Posługując się rozróżnieniem terminologicznym Gideona Touriego (Toury 1986: 1112) na tłumaczenie, przekładalność i przekład (tłumaczenie - jako sama operacja przełożenia tekstu z jednego systemu na drugi; przekładalność - jako możliwość uzyskania w miarę optymalnej ekwiwalencji między tekstami w różnych systemach, oraz przekład - jako tekst w jednym systemie, który zakłada istnienie wcześniejszego chronologicznie i logicznie tekstu w drugim systemie), można postawić hipotezę, że podział pierwotnie spójnego systemu na szereg systemów odrębnych - czyli rozpad jednego starożytnego języka na kilka języków nowożytnych lub sztuki pierwotnie synkretycznej na kilka odrębnych sztuk - pociągnął za sobą automatycznie powstanie między nimi zjawiska przekładalności. Przekładalność stała się wówczas „reliktem” wskazującym na pierwotny związek, a proces przekładu, podejmowany z wiarą w możliwość optymalnej ekwiwalencji, jest podświadomym rezonansem kulturowej pamięci, przypominającej sobie niejako, że systemy te tworzyły kiedyś jedną całość.

Nie będziemy tu rozstrzygać, jak daleko rozciąga się omawiane podobieństwo między przekładalnością sztuk pierwotnie synkretycznych a przekładal-

1 Można by go nazwać polifonicznym, gdyby ten termin nie był zarezerwowany dla określonej konwencji w muzyce.

2 Analizy litanii w różnych sztukach zawarte są w książce pod redakcją Witolda Sadowskiego i Francesco Marscianiego (zob. Sadowski, Marsciani 2020). Por. m.in. panorama perspektyw badawczych w rozdziale: Sadowski, Kowalska, Kubas 2020: 1-24. 
nością zachodzącą między językami. W obręb analogii wypada jednak zaliczyć jeszcze jeden element wskazany przez Touriego. Izraelski badacz, powołując się na Itamara Evena-Zohara, do czynników sprzyjających przekładalności zaliczył między innymi samą bliskość języków (Toury 1986: 1123). W tłumaczeniu bowiem nie tylko borykamy się $\mathrm{z}$ ich rozgraniczeniem na lingwistycznej mapie świata, lecz bierzemy także pod uwagę stopień ich oddalenia. O jednym języku obcym można powiedzieć, że jest usytuowany sprzyjająco blisko, podczas gdy w stosunku do drugiego trzeba skonstatować, że w jakimś swoim zakresie znalazł się już zbyt daleko, by było jeszcze możliwe sprowadzenie stamtąd na nasz teren określonych treści semantycznych. Wydaje się, że wpływ na przekładalność stopniowego oddalania się od siebie systemów dotyczy nie tylko relacji lingwistycznych, lecz także tłumaczenia sztuk wywodzących się z synkretycznej wspólnoty.

Jak już zostało wspomniane, w starożytności i średniowieczu litania była nie tylko dziełem poetyckim czy wokalnym. Nie ograniczała się też jedynie do wydarzenia paraliturgicznego, społecznego czy politycznego. Nosiła cechy wypowiedzi filozoficznej. Korespondowała mianowicie z neoplatońskim założeniem, że ludzkie zmysły oszukują nas na temat stosunków między bytami, a prawdziwa struktura czasoprzestrzeni ma charakter teocentryczny. Była więc wyrazem określonego światopoglądu, zgodnie z którym elementy rzeczywistości, wbrew informacjom sensualnym, nie obracają się ani wokół ziemi, ani wokół słońca, lecz orientują się względem Boga, od którego czerpią egzystencję. Zależność całej nieskończonej różnorodności bytów od jednego i niezmiennego, czyli wciąż tego samego, Stwórcy wyrażana była artystycznie w postaci charakterystycznego litanijnego zestawienia wyrazów (czy formuł), które powtarzają się jednakowo w dużej partii tekstu, z wyrazami (lub wyrażeniami) zmiennymi, lecz względem siebie paralelnymi (Sadowski 2018: 236-242, 248-258).

Te religijne założenia były proklamowane w samej strukturze litanii i w zasadzie nie wymagały werbalizacji. Ówczesnego człowieka w kosmologicznych przeświadczeniach utwierdzały bowiem sztuki plastyczne, odwołujące się do tego samego schematu, lecz w inny sposób. Wystarczyło spojrzeć na bizantyjskie mozaiki w sklepieniach półkolistych czy witraże rozetowe gotyckiej katedry, by zorientować się, że elementy przedstawienia rozłożone cyrkularnie wokół Boskiego centrum komunikują tę samą wiedzę na temat czasoprzestrzennej tkaniny świata (Sadowski 2018: 242-248).

Tak było jeszcze w średniowieczu. Nasuwa się jednak pytanie, jak długo owa strukturalna semantyka litanii pozostawała dla Europejczyków czytelna pytanie dotyczące trwałości znaczeń przekazywanych w gatunku, a więc w badaniach filologicznych niemające łatwych odpowiedzi. W jaki sposób ustalić, 
czy człowiek xIx lub xx wieku, obcując z tekstem litanijnym (czy to w postaci modlitwy kościelnej, czy to w formie utworu poetyckiego), miał nadal poczucie zakotwiczenia gatunku w teocentrycznej wizji kosmosu - tak jak miał ją niewątpliwie człowiek wieków średnich? Czy różne sztuki, dziedziczące składniki tej starodawnej spuścizny, oddaliły się od siebie tak bardzo, że nie są już w stanie przechowywać pamięci o tym, co je kiedyś łączyło? Czy wręcz przeciwnie, pomimo rozpadu na niezależne nurty zakładają nadal wspólny obraz świata?

Niewątpliwie, dla przytłaczającej większości współczesnych czytelników litanii opisana wyżej koncepcja czasoprzestrzeni pozostaje nieznana. Z pewną pomocą przychodzą tu jednak przekłady interesemiotyczne. Każda próba przetransponowania tekstu litanii na obraz, która prowadzi do struktury koncentrycznej, oznacza bowiem, że kosmologiczne założenia gatunku zostają w jakiejś mierze ponownie ujawnione. Warunki te spełnia między innymi witraż opracowany w latach trzydziestych xx wieku dla katedry NMP w Reims, na którym alegoryczne reprezentacje wezwań Litanii loretańskiej orbitują na okręgach wytyczonych wokół centralnego wizerunku Maryi z Dzieciątkiem (Sadowski 2016: 61-64; 2018: 246-247). Nie dysponujemy informacjami, czy autor rozety, Jacques Simon, wpadł na ten pomysł automatycznie, czy téz namalowanie witraża było poprzedzone dogłębnymi studiami, czy wręcz jakimś rodzajem kontemplacji, w trakcie której trzeba było przełamać w sobie początkowe niezrozumienie teologicznych założeń gatunku. Patrząc jednak na ostateczny rezultat, można zauważyć, że gatunkowy obraz świata litanii stał się dla tego artysty w pełni dostępny, podobnie jak nie ulega wątpliwości, że jego dzieło nie może być traktowane jako dowód na czytelność semantyki litanii dla wszystkich europejskich użytkowników wszelkiego typu tekstów wyliczeniowych. Wiek xx przynosi tu raczej dane zróżnicowane, co pokazują między innymi utwory z nurtu poezji konkretnej.

Poezja konkretna dobrze nadaje się do studiów nad reminiscencjami z pierwotnej jedności sztuk literackich i plastycznych, ponieważ w bardzo wielu swoich nurtach stara się dokonywać ponownego scalenia słowa i obrazu czy wręcz zjednoczenia słowa i przedmiotu, słowa i sztuk operujących materiałem fizycznym. Jednym z jej najczęstszych narzędzi są permutacje, które dla wielu czytelników stanowią odpowiedź na cybernetyczną współczesność, lecz których logika opiera się na wyliczaniu wariantów sugerujących jakiś jeden centralny model czy prawzorzec. Nie od rzeczy będzie więc zapytać, do jakiego stopnia myślenie konkretystów w kategoriach systemów i powtórzeń jest zakotwiczone w gatunkowym obrazie świata litanii. Należyte rozpatrzenie tego problemu w odniesieniu do różnorodnych odmian poezji konkretnej wymagałoby oczywiście dłuższej rozprawy. Główną hipotezę można jednak wysunąć już teraz: 
czytelność litanijnej semantyki kształtuje się odmiennie w zależności od obszaru językowo-kulturowego. Żeby się o tym przekonać, wystarczy porównać ze sobą przykłady pochodzące z polskiej i niemieckojęzycznej poezji konkretnej drugiej połowy xx wieku.

Twórczość konkretystów będzie tu opisywana jako zjawisko powojenne. Wprawdzie nie ma w tym założeniu nic kontrowersyjnego, warto jednak podkreślić, że mimo wpływu na poezję konkretną przedwojennych ruchów awangardowych fundamentalna dla niej kwestia osadzenia sztuki w czasie i przestrzeni spowodowała daleko idącą redefinicję odziedziczonych po dadaizmie czy futuryzmie technik artystycznych. Wymalowanie utworu literackiego wielkimi literami na ścianie kamienicy uświadamiało, że techniki te nasiąkają miejscem i momentem ich użycia w powojennym - niekoniecznie literackim - kontekście miejskich uwarunkowań. To samo tyczy się zresztą wydawnictw i serii wydawniczych. Ponieważ „książkę konkretystyczną charakteryzuje przemyślana relacja między poezją konkretną a sposobem i miejscem jej wydania” (Kremer 2015: 117), utwór opublikowany w oficynie związanej z określonym ośrodkiem miejskim nie powinien być bezrefleksyjnie reprodukowany w dowolnie wybranym innym wydawnictwie. Należy to uszanować także w niniejszym artykule, w którym ilustracje i cytaty mają raczej odsyłać do utworów, niż je przywoływać.

W grę wchodzi tu zresztą nie tylko miejsce publikacji, lecz także czas. Na przykład utwór Eugena Gomringera składający się z czterech tekstowych kwadratów w układzie szachownicy dwa na dwa (każdy kwadrat wypełniony dwunastoma linijkami tekstu i każdy obrócony o 90 stopni względem kwadratów sąsiadujących) ukazał się pierwotnie na karcie tłoczonego papieru, przypominającej składaną kartkę z życzeniami. Po jej rozłożeniu widać go było na lewym skrzydle, mającym również formę kwadratu, na którym zajmował środkową część, jakieś 10 procent na tle pozostałej pustej przestrzeni (Gomringer 1975). Tak wydany w Düsseldorfie na przełomie 1975 i 1976 roku, nie może być odbierany jako dokładnie ten sam utwór, który ukazał się w roku 1977 w antologii dzieł Gomringera w Stuttgarcie, w małej kieszonkowej książeczce na ekonomicznej jakości papierze, ściśle wypełniając sobą przestrzeń między lewym i prawym marginesem (Gomringer 1977: 71). Różnice dotyczące charakteru publikacji oraz jej formatu, papieru i składu mają w tym wypadku znaczenie, podobnie jak transformacja samego tekstu dzieła, który w ciągu około dwóch lat, jakie upłynęły od pierwodruku, zdążył się jak gdyby obrócić w prawo. Lewy górny kwadrat, który dawał się pierwotnie czytać horyzontalnie, znalazł się teraz w prawym górnym rogu, dodatkowo obrócony rotacyjnie o 90 stopni. I analogicznie, zgodnie ze wskazówkami zegara, przesunęły się też i obróciły prostopadle pozostałe kwadraty, tak że lektury horyzontalnej nie umożliwia już 
kwadrat umieszczony po lewej stronie na górze, lecz jego rolę przejął kwadrat znajdujący się w prawym rogu na dole - ten sam, który rozpoczyna się znamiennymi w tym kontekście zdaniami: „jeder hört es anders”, „jeder sagt es anders”, ,jeder sieht es anders” [każdy słyszy to inaczej / każdy mówi to inaczej / każdy widzi to inaczej].

Jak we wszystkich kwadratach, tak też i w tym, który w wydaniu stuttgarckim zajął pozycję horyzontalną, takich zdań jest w sumie dwanaście, zapisanych jedno pod drugim. Wszystkie zaczynają się anaforą „jeder” [każdy] z dołączonym do niej czasownikiem w trzeciej osobie liczby pojedynczej, zmieniającym się z linijki na linijkę (słyszy, mówi, widzi, pisze, czuje, czyta, trzyma, szuka, pożąda, robi, nosi, chwyta). Wszystkie kończą się też epiforą „es anders” [to inaczej], z wyjątkiem linijki czwartej - tak wydrukowanej, by sugerować, że nieco dłuższe rozmiary czasownika „schreibt” [pisze] spowodowały przekroczenie granic kwadratu i w rezultacie dwie litery z końca wyrazu „anders” musiały zostać ucięte gilotyną marginesu. Zamiast pełnej formuły „każdy pisze to inaczej” otrzymujemy coś w rodzaju „każdy pisze to inacz”.

Pozostałe kwadraty stanowią permutacje modelu opisanego na tym przykładzie, przy czym nie ulega zmianie zestaw czasowników, zmienia się natomiast ich kolejność, a także forma gramatyczna anafory i wyraz epiforyczny. Zachowana zostaje też reguła, że linijka odnosząca się do pisania nie mieści się w przewidzianych ramach tekstu, choć zajmuje za każdym razem inne miejsce w danym kwadracie: nie czwarte (jak wyżej), lecz jedenaste, dwunaste lub piąte.

Tak pomyślany tekst utworu może kojarzyć się z litanią ze względu na połączenie elementów stałych i zmiennych przypominające paralelne wezwania („jeder hört”, „jeder sagt”, „jeder sieht” itd.), na które pada responsoryjna odpowiedź „es anders”, „es anders”, „es anders”... Osadzenie kwadratów na szachownicy w taki sposób, który sugeruje ich obrót, jak również rotacja całej konstelacji między jednym a drugim wydaniem utworu mogą zaś sugerować, że cała struktura orbituje wokół jakiegoś jednego centralnego punktu, zgodnie ze średniowieczną wizją kosmologiczną i gatunkowym obrazem świata litanii. Do tego momentu nie mamy kontrargumentów przeciwko tezie, że dzieło Gomringera wpisuje się w litanijną tradycję. Wątpliwości zasiewa dopiero warstwa werbalna utworu, ujawniająca coś w rodzaju pęknięcia czy rozwarstwienia między idealnym koncentrycznym modelem a wypowiedzią, która nie zawsze potrafi się w tym modelu pomieścić. Tym zjawiskiem, które bezskutecznie próbuje przełamać ramy czasoprzestrzeni, jest zaś czynność pisania, która nigdzie nie deklaruje swojego spełnienia, choć w poszczególnych kwadratach próbuje przyjmować różne podmiotowe i przedmiotowe konfiguracje: „jeder schreibt es ande" (każdy pisze to inacz[ej]), „jede schreibt sich sel” (każda pisze siebie 


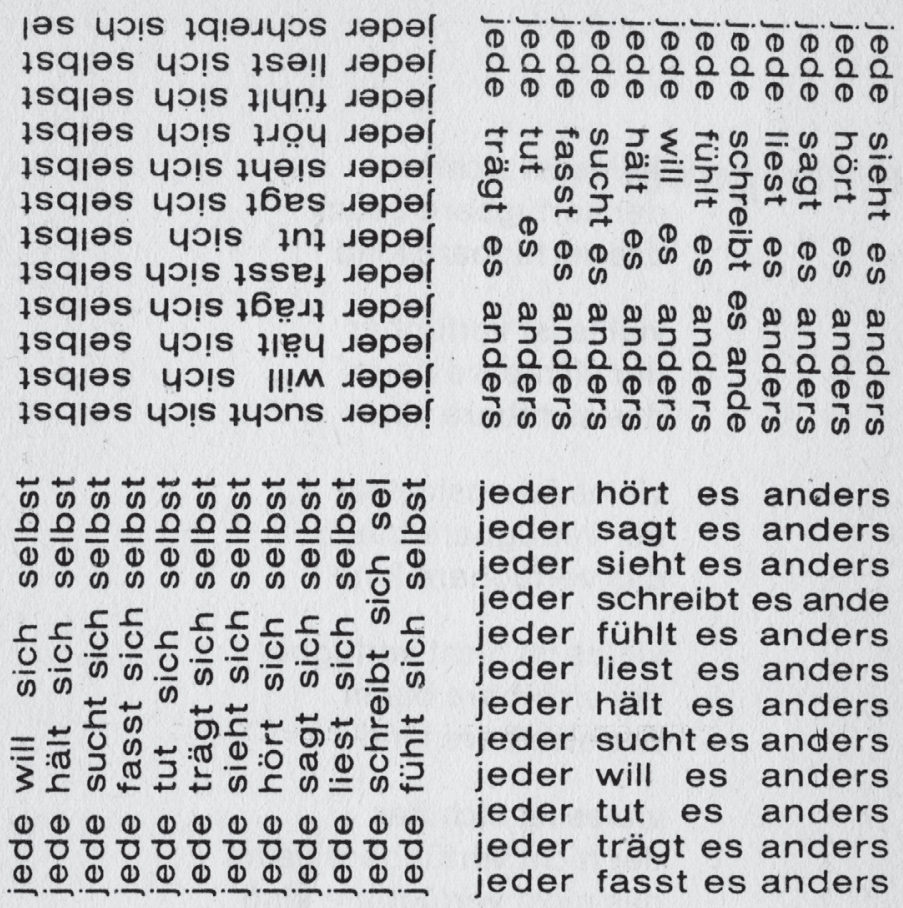

las 40!s 7q!əג40s дәрә!

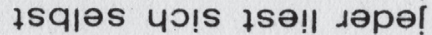
tsqiəs 4ọs tlun! depe! tsqlas yग!s thou depe!

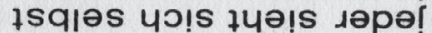
tsqlas 4ગ!s tbes tsqies yo!s fnt sepe!

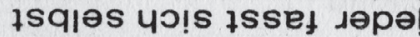
tsqiəs 40! $76 e$ t

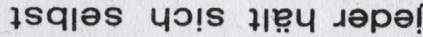
tsqies 4ગ!s II!M 1әpe! tsqios yo!s tuons 1әpe!

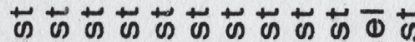

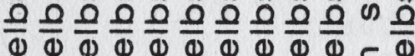

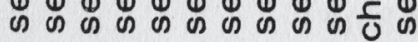

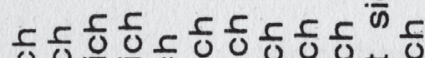

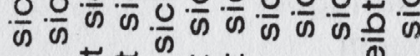

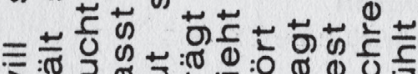

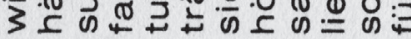

(1) (1) (1) 0

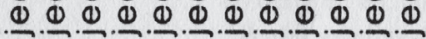

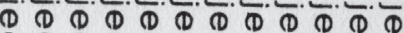
D $\frac{O}{D} \frac{O}{D} \frac{O}{D} \frac{O}{D} \frac{O}{D} \frac{O}{D} \frac{O}{D} \frac{O}{D} \frac{O}{D}$

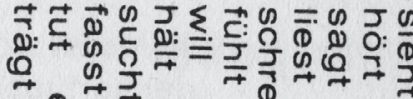
(1) ๑

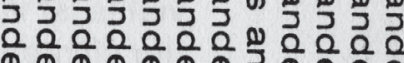
के के ले के ले के के ले

jeder hört es anders jeder sagt es anders jeder sieht es anders jeder schreibt es ande jeder fühlt es anders jeder liest es anders jeder hält es anders jeder sucht es anders jeder will es anders jeder tut es anders jeder fasst es anders

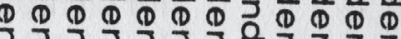

Ryc. 1. Eugen Gomringer, utwór bez tytułu w wersji z wydania stuttgarckiego (Gomringer 1977: 71). (C) Eugen Gomringer, 1977. Autor artykułu dziękuje Eugenowi Gomringerowi za zgodę na zamieszczenie reprodukcji. Ta i kolejne ilustracje w artykule są chronione prawem autorskim i nie mogą być dalej powielane bez zgody właścicieli tych praw.

sa[ma]), „jeder schreibt sich sel” (każdy pisze siebie sa[m]), „jede schreibt es ande" (każda pisze to inacz[ej]).

U Gomringera nie wydaje się zatem problemem sama dostępność lub czytelność litanijnego obrazu świata. Tekst utworu zostaje wszak skojarzony z właściwym układem przedstawienia plastycznego, a pomysłowa rotacja między jednym wydaniem a drugim utwierdza nas w przekonaniu, że z zasobów gatunkowych nie zostaje przywołana sama tylko określona koncepcja spacjalna, 
koncepcja przestrzeni, lecz gatunek litanii odsłania przed czytelnikiem swoją pełną, wielowymiarową, koncentryczną czasoprzestrzeń. W utworze Gomringera nie chodzi więc o problem z dostępnością wizji kosmologicznej. Chodzi o problematyczność funkcjonowania w tej wizji aktu pisarskiego.

Dalszą interpretację dzieła zostawiamy czytelnikom, przechodząc do drugiego autora kojarzonego z nurtem poezji konkretnej - Ernsta Jandla, w którego tekstach asocjacje litanijne ujawniają się częściej i wyraźniej niż w pracach Gomringera, zwykle dalekich od litanii. W twórczości poety austriackiego szczególną uwagę przykuwa utwór der blitz (błyskawica), opublikowany w tomiku Laut und Luise z 1966 roku. Dzieli się on na dziewięć części, z których każda

\section{hohe gegenstände werte gegenstände geehrte gegenstände verehrte gegenstände erlauchte gegenstände sehrgeehrte gegenstände sehrverehrte gegenstände hochzuverehrende gegenstände hochverehrte gegenstände hochgeehrte gegenstände erlauchte gegenstände verehrte gegenstände geehrte gegenstände werte gegenstände hohe gegenstände}

Ryc. 2. Ernst Jandl, der blitz, fragment (Jandl 1997: II-105). Ernst Jandl, Werke, hrsg von Klaus Siblewski (c) 2016 Luchterhand Literaturverlag, München, in der Penguin Random House Verlagsgruppe GmbH. 
zajmuje osobną stronę. Litanijny charakter widać już na stronie pierwszej. Tekst rozpoczyna się krótkim opisem błyskawicy (sunącej zygzakiem po niebie i porównanej do węża), by następnie przejść do wyliczenia piętnastu „gegenstände” [przedmiotów] poprzedzonych coraz dłuższymi, a następnie coraz krótszymi przymiotnikami. Kolejne linijki składają się zatem z określeń, które można przetłumaczyć jako: wysokie przedmioty, wartościowe przedmioty, zaszczytne przedmioty, czcigodne przedmioty itd.

Nils Bernstein, analizując ten fragment, dostrzegł w nim grę z frazeologizmem „meine Damen und Herren” [Panie i Panowie], którego popularne hiperbolizacje polegają w języku niemieckim na rozszerzaniu wyjściowego zwrotu o dodatkowe epitety, tożsame z niektórymi przymiotnikami z utworu Jandla (np. „meine geehrten Damen und Herren” czy „meine verehrten Damen und Herren", Bernstein 2011: 96). Skojarzenie to wydaje się trafne, warto jednak rozważyć także inny trop lekturowy, jako że seria epitetów spiętych epiforą może też przypominać litanijne wyliczanie cnót świętego. Tak jakby to nie był inwentarz przedmiotów czy nawet ich poetycki opis, lecz raczej seria pochwalnych wezwań pod ich adresem, dzielących się na kunsztowny epitet (zmieniający się z linijki na linijkę) i responsoryjną odpowiedź (która pozostaje stała w całym wyliczeniu).

O ile jednak lektura pierwszej strony der blitz jako litanii ma uzasadnienie w strukturze składniowej tekstu, o tyle nie znajduje jednoznacznego wsparcia w obrazie wyłaniającym się z zapisu poszczególnych linijek. Podobnie jak to było w utworze Gomringera, pierwsza część poematu Jandla przykuwa wprawdzie uwagę swoim graficznym kształtem, jednakże, inaczej niż tam, obraz uzyskany przez austriackiego poetę zdaje się świadczyć bądź o niewiedzy, jakiego typu wizja czasoprzestrzeni powinna korespondować z litanią (niewiedzy rzeczywistej lub tylko pozorowanej), bądź też o próbie wyparcia z utworu tradycyjnej semantyki gatunku. Chociaż zapis przyjmuje tu formę gradacyjną, skupiając epitety wokół linijki najdłuższej, to jednak nie wydaje się wynikać z koncepcji teocentrycznej. Ma rację Bernstein, uważając, że niebagatelną rolę w każdej przytoczonej parze wyrazów odgrywa wydłużona spacja między przymiotnikiem i rzeczownikiem. Można ją interpretować jako próbę odzwierciedlenia w zapisie toru przecinającej niebo błyskawicy (Bernstein 2011: 96). Na rzecz opinii Bernsteina świadczy między innymi sposób wykorzystania tego fragmentu w edycji utworów Jandla adresowanej do dzieci. Uwzględniono w niej tylko pierwszą stronę poematu, ilustrując ją kolorowym obrazkiem przedstawiającym burzę, w czasie której zygzakowaty piorun uderza w spiczasty czubek pagórka wysunięty w kierunku stalowej chmury (Jandl 20o8: 8-9)3. Gdybyśmy więc nawet

3 Książkę można obejrzeć w internecie: https://tinyurl.com/fsah2j87 [dostęp: 1.09.2020]. 
powiedzieli, że wezwania z litanii Jandla, grupując się koncentrycznie, wskazują razem na niebo, to byłoby to raczej niebo atmosfery niż ukryta przed światem, metafizyczna siedziba Stwórcy kosmosu. Litania została tu potraktowana jako puste znaczeniowo narzędzie, dające się swobodnie zaprzęgać do pomysłów artystycznych poety i niewnoszące do utworu własnego semantycznego wiana.

Taki pogląd na litanię potwierdza się zresztą w jednej z prac naukowych Jandla występującego jako badacz literatury. Znamienny jest mianowicie jego esej na temat składni poetyckiej w tomikach Friederike Mayröcker, autorki, z którą był związany przez kilkadziesiąt lat. Jandl w swojej analizie skupia uwagę m.in. na utworach pochodzących z wczesnej twórczości austriackiej poetki, które sam nazywa litaniami i które omawia, całkowicie abstrahując nie tylko od pytania o semantykę gatunku, lecz nawet od niepodważalnego przecież genetycznego związku litanii z modlitwą kościelną. Litania w świetle tego artykułu to po prostu przykład istnienia „systemów składniowych zbudowanych z jednego lub kilku elementów stałych, do których dołączane są elementy zmienne" (Jandl 1979: 246). Rola takiego systemu wydaje się badaczowi czysto syntaktyczna: litania pozwala na pisanie wierszy pozbawionych formalnie zdań, tak

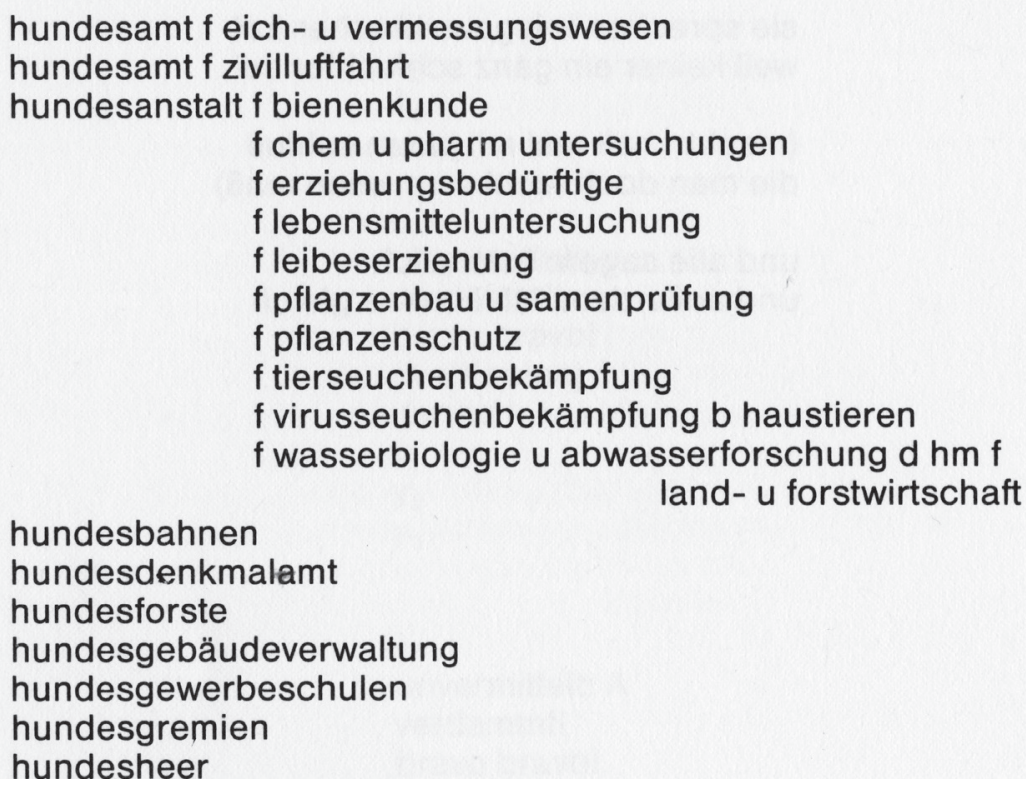

Ryc. 3. Ernst Jandl, hundeshymne, fragment (Jandl 1997: VI-186). Ernst Jandl, Werke, hrsg von Klaus Siblewski ( 2016 Luchterhand Literaturverlag, München, in der Penguin Random House Verlagsgruppe GmbH. 
jednak skonstruowanych, by dzięki paralelizmowi czytelnik nie miał poczucia, że brakuje składni. Jeżeli jeden z utworów Mayröcker zostaje słowami Jandla zaklasyfikowany jako „wiersz emocjonalny”, natychmiast pojawia się dopowiedzenie, że należy przez to rozumieć formułę „bardziej w sensie «emocji» Huxleya niż w dawnej liryki «uczuć»”, zaś efekt semantyczny, w którym „wszystko jest po prostu «czymś na kształt»": miejscami „nieuchwytne i nieostre, a potem znowuż klarowne i wyraźnie widoczne” (Jandl 1979: 247), wyprowadza Jandl z charakteru słów w utworze, a nie z zasobów gatunku.

Nic więc dziwnego, że także w wielu własnych utworach Jandla litania okazuje się wydmuszką, która zachowała w nienaruszonym stanie swój składniowy szkielet, lecz zupełnie zatraciła semantyczną istotę. W takich poematach jak hundeshymne (psi hymn) prowadzi to siłą rzeczy do zatarcia granic między litanią i biurokratycznym rejestrem.

Potraktowanie rozmaitego typu wyliczeń, jakie wypracowała kultura, na zasadzie rozmaitych „systemów składniowych” w konsekwencji pozbawia zaś poezję możliwości czerpania znaczeń z różnicy, jaka się między nimi kształtuje. Nie oznacza to, że w żadnym tomiku Jandla nie ma próby dialogu $\mathrm{z}$ teocentrycznym obrazem świata litanii. Za taką próbę można uznać utwór von keit zu keit - ein lebensplan (od ości do ości - plan na życie) z wielokrotną aklamacją „amen”.

Tego rodzaju poetyckie próby nie wykraczają jednak poza sytuację omówioną już przy Gomringerze: religijne odniesienia gatunku pozostają czytelne, lecz słowo poety jak gdyby nie potrafi się odnaleźć w założonych ramach czasoprzestrzennych.

Na tym tle zupełnie inny wydźwięk mają dzieła niektórych konkretystów polskich. Znana instalacja Stanisława Dróżdża Między, prezentowana pierwotnie w Galerii Foksal, a następnie w postaci innych analogicznych projektów ${ }^{4}$, może być rozpatrywana porównawczo ze wspomnianą pracą Gomringera. Dróżdż bowiem - podobnie jak Gomringer - sięgnął po formę czworokątów, stykających się ze sobą i zorientowanych wokół wspólnego centrum, na których wypisano tekst - tym razem w postaci kilkudziesięciu pozornych anagramów leksemu „między”. Pozornych, ponieważ w kreowanych neologizmach nigdy nie zostają wykorzystane wszystkie litery tego słowa, otrzymujemy raczej zbiór niekom-

4 Zdjęcia i prezentacje instalacji można znaleźć w internecie, np. na stronie Muzeum Sztuki w Łodzi w zakładce „Artyści” (https://zasoby.msl.org.pl), na stronie Muzeum Sztuki Współczesnej w Krakowie (https://www.mocak.pl/artist/176/miedzy) i na portalu Wirtualne Muzea Małopolski w grupie obiektów z Muzeum Sztuki Współczesnej w Krakowie (http://muzea.malopolska.pl/obiekty) [dostęp 01.09.2020]. 


\section{von ewigkeit zu ewigkeit}

amen

von fähigkeit zu fähigkeit

amen

von festigkeit zu festigkeit

amen

von festlichkeit zu festlichkeit

amen

von findigkeit zu findigkeit

amen

von freundlichkeit zu freundlichkeit

amen

von friedlichkeit zu friedlichkeit

amen

von frömmigkeit zu frömmigkeit

amen

Ryc. 4. Ernst Jandl, von keit zu keit - ein lebensplan, fragment (Jandl 1997:

VI-195). Ernst Jandl, Werke, hrsg von Klaus Siblewski ( 2016 Luchterhand Literaturverlag, München, in der Penguin Random House Verlagsgruppe $\mathrm{GmbH}$.

pletnych prób jego wypowiedzenia. Co jednak najciekawsze, widz, oglądający te wszystkie permutacje, nie ma najmniejszego kłopotu z identyfikacją wyrazu źródłowego, co w intrygujący sposób obnaża metafizyczną oczywistość centralnego modelu. Podstawowa różnica między Dróżdżem a Gomringerem nie polega więc tylko na innym podejściu do błędu w systemie, który dla twórcy niemieckiego był elementem destabilizującym porządek, a który dla polskiego twórcy stał się właśnie dowodem na istnienie wpisanych w system relacji

5 Tadeusz Sławek swoim artykule na temat przyimków Dróżdża i ich teologicznych odniesień stwierdza między innymi: „Czyli z Bogiem jestem związany. Nie jako «ja», lecz jako «nic», które «między»" (Sławek 2007). 
Zasadnicza rozbieżność wynika z kształtu instalacji przyjętego przez Dródża. Artysta zaplanował swoje czworokąty jako ściany pokoju, do którego widz może fizycznie wejść i w którym może się symbolicznie zadomowić, sprawdzając w ten sposób, jak się odnajdzie „w roli «obywatela» wiersza” (Sławek 1989: 55). O ile więc pisanie było tym aspektem utworu Gomringera, który w żadnym wariancie nie dawał się w jego konstelacji pomieścić, o tyle u Dróżdża czasoprzestrzeń dzieła nie tylko nie wyklucza podmiotu ze swojego obszaru, ale dopiero po zaproszeniu go do środka i osadzeniu „między” jej wektorami odsłania przed nim źródłowe słowo, nigdzie niezwerbalizowane, będące niczym innym jak właśnie owym „między”, którego podmiotowi nie jest wprawdzie dane przeczytać (ani tym bardziej napisać), ale którego niewątpliwie doświadcza.

Nie o Dróżdżu chcemy tu jednak mówić. Jego słynne dzieło musiało zostać przywołane, ponieważ razem $\mathrm{z}$ nim - w ramach relacji intertekstualnej - należy rozpatrywać inny interesujący nas utwór, a właściwie fragment utworu Marianny Bocian $Z$ ślepcem przez pustynię. W środku tego dramatu w dialog między postaciami wcina się - jak informują didaskalia - „bardzo spokojny głos «litanii konkretnej»" (Bocian 1979: 211). Jest to jedyne znane nam dzieło artystki, którego struktura i treść werbalna tak ostentacyjnie osadzają litanijną formę w ramach konkretyzmu. Tekst tej litanii zajmuje w całości osobną stronę książki, wydrukowany mniejszą czcionką niż pozostała część utworu - prawdopodobnie po to, żeby nikt nie przeoczył znaku krzyża, w który ta litania została graficznie wkomponowana.

Forma krzyża stanowi od wieków ugruntowaną konwencję poezji wizualnej (Higgins 1987: 6-8, 36-37 i wiele innych przykładów w tomie; Bohn 2011: 26-27, 34). Było ją zresztą już widać u Gomringera. Tam jednak układ dwóch przecinających się pasów - pionowego i poziomego - zdawał się stanowić przygodną konsekwencję modelu szachownicy. Tekst utworu nie zdradzał żadnej świadomości, że sąsiaduje z krzyżem. Nie zawiązywały się jakiekolwiek czytelne interferencje między wypowiedzią słowną a religijnym symbolem. Sama forma krzyża nie była zresztą oczywista. Symetrycznie przecinające się linie w połączeniu z rotacją tekstu jakiemuś odbiorcy mogą się przecież skojarzyć ze swastyką. „Każdy widzi to inaczej” (Gomringer 1977: 71).

W całej zróżnicowanej formalnie twórczości - rozpinającej się między sztuką słowa i sztuką obrazu - Bocian prezentuje całkowicie odmienne podejście do krzyża. Symbol ten był w jej dziełach świadomie wybierany, wskazywany i eksponowany, odgrywając w nich zawsze przemyślaną rolę:

Znak krzyża, który pojawiał się w realizacjach Marianny Bocian od 1971 roku, najwyraźniej zaistniał podczas ekspozycji Ścieżka języka. 
Przyjął wówczas status symbolu języka umęczonego i upokorzonego, języka rozpiętego na ramionach znaku. Poprzez odwoływanie się do symboliki chrześcijańskiej artystka ujawniła swój system wartości oraz rolę języka w procesie zbawienia - jak określała zachowanie narodowej tożsamości (Dawidek-Gryglicka 2012: 230).

Przyjrzyjmy się, w jaki sposób znak krzyża został wypełniony tekstem $\mathrm{w}$ dramacie $Z$ ślepcem przez pustynię. Poziomą belkę tworzy tu zbiór 113 wyrazów rozpisanych w ośmiu linijkach, na które składają się różne formy czasownika „być” i rzeczownik „życie” - słowa o ewidentnie ewangelicznym rodowodzie, dla których w Nowym Testamencie dałoby się wskazać wiele sensotwórczych motywacji. By nie mnożyć dobrze znanych przykładów, niech wystarczą dwa cytaty z Ewangelii Janowej, oba wypowiedziane przez Jezusa w perspektywie Pasji: „Gdy wywyższycie Syna Człowieczego, wtedy poznacie, że Ja jestem” $(\mathrm{J} 8,24)$ oraz „Nikt nie ma większej miłości od tej, gdy ktoś życie swoje oddaje za przyjaciół swoich” (J 15,13) ${ }^{6}$. W świetle tradycji chrześcijańskiej zaktualizowane przez Bocian skojarzenie życia, bycia i krzyża nie wydaje się gestem ekstrawaganckim, jest raczej przejawem intelektualnej prostoty.

Belka pozioma znajduje się nieomal w samym środku „litanii konkretnej”, przecinając się z belką pionową, której górna część przywodzi na myśl wcześniej przywołaną instalację Dróżdża (Bocian 1979: 211).

$\begin{array}{rll}\text { słowo } & \text { MIĘDZY } & \text { słowem } \\ \text { czas } & \text { MIĘDZY } & \text { czasem } \\ \text { pragnienie } & \text { MIĘDZY } & \text { pragnieniem } \\ \text { tworzenie } & \text { MIĘDZY } & \text { tworzeniem } \\ \text { krzyk } & \text { MIĘDZY } & \text { krzykiem } \\ \text { śmiech } & \text { MIĘDZY } & \text { śmiechem } \\ \text { piach } & \text { MIĘDZY } & \text { piachem } \\ \text { litera } & \text { MIĘDZY } & \text { literą } \\ \text { zdanie } & \text { MIĘDZY } & \text { zdaniem } \\ \text { sekunda } & \text { MIĘDZY } & \text { sekundą } \\ \text { kain } & \text { MIĘDZY } & \text { kainem } \\ \text { abel } & \text { MIĘDZY } & \text { ablem } \\ \text { miłość } & \text { MIĘDZY } & \text { miłością } \\ \text { dotyk } & \text { MIĘDZY } & \text { dotykiem } \\ \text { cios } & \text { MIĘDZY } & \text { ciosem } \\ \text { ból } & \text { MIĘDZY } & \text { bólem } \\ \text { krew } & \text { MIĘDZY } & \text { krwią } \\ \text { dawanie } & \text { MIĘDZY } & \text { dawaniem } \\ \text { branie } & \text { MIĘDZY } & \text { braniem }\end{array}$

6 Cytaty z Pisma św. podaję za Biblią Tysiąclecia (wyd. 4). 


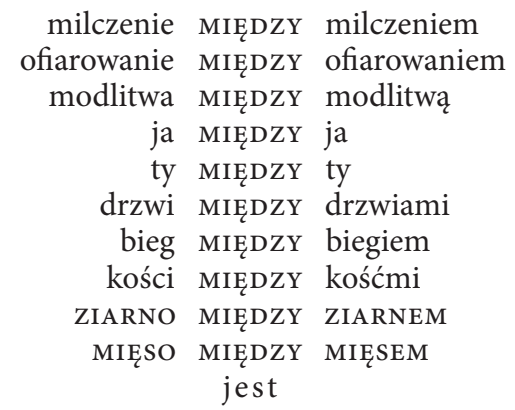

żYCIE życie żYCIE życie żYCIE życie żYCIE życie żYCIE życie żYCIE życie jestem JESTEM jestem JESTEM jestem JESTEM jestem JESTEM jestem JESTEM ŻYCIE jesteś ŻYCIE jesteś ŻYCIE jesteś ŻYCIE jesteś ŻYCIE jesteś ŻYCIE jesteś ŻYCIE jesteś ŻYCIE jesteś ŻYCIE jesteś ŻYCIE jesteś ŻYCIE jesteś JEST życie JEST życie JEST życie JEST życie JEST życie JEST życie JEST życie ŻYCIE jest żYCIE jest ŻYCIE jest żYCIE jest żYCIE jest żYCIE jest żYCIE jest JEST ŻYCIE JEST ŻYCIE JEST ŻYCIE JEST ŻYCIE JEST ŻYCIE JEST ŻYCIE JEST życie żYCIE życie żYCIE życie żYCIE życie żYCIE życie żYCIE życie żYCIE JEST jest JEST jest JEST jest JEST jest JEST jest JEST jest JEST jest JEST jest

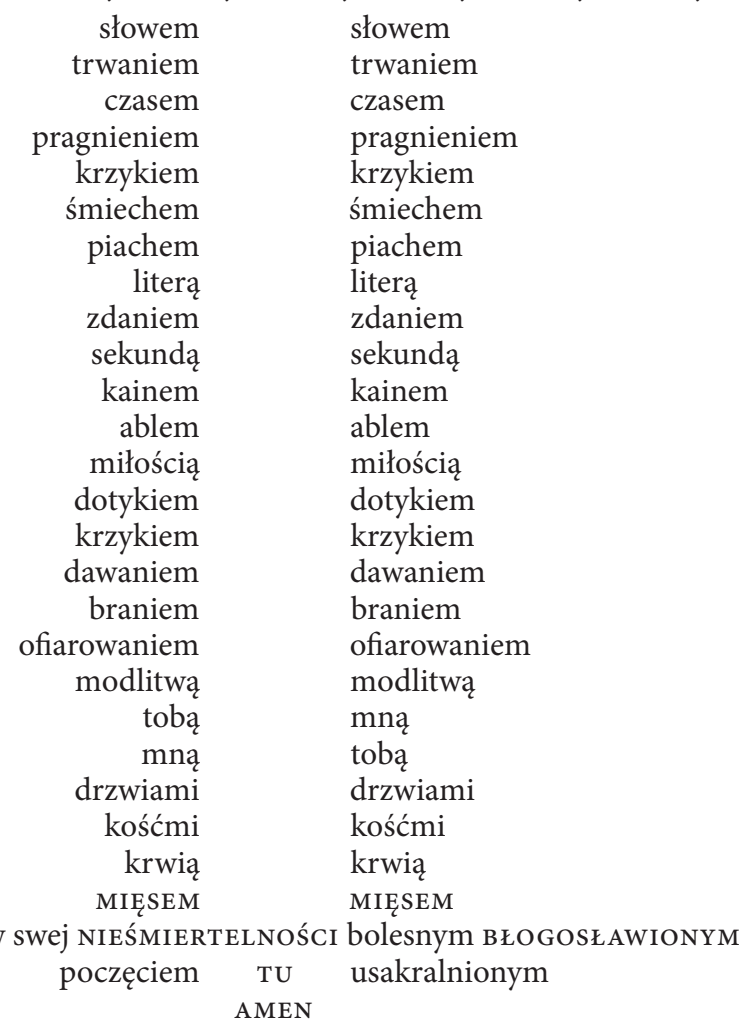


W ramach całości przedstawienia przyimek „MIĘDZY” nie może być odczytywany czysto gramatycznie, zredukowany do składniowej funkcji konektora, ponieważ towarzysząc kolejnym pojęciom wypisanym na pionowej belce krzyża, zdaje się urastać do rangi jak gdyby jednej z osi świata, przecinającej od góry poziomą oś bycia i życia, by następnie przeistoczyć się na dole w pozornie pustą przestrzeń wynikającą z rozdzielenia wyrazów nieco dłuższą niż konwencjonalnie spacją. Rozmiary tej spacji są mniej więcej takie jak u Jandla. Jakże inaczej przedstawia się jednak znaczenie tej pustki. Gdy prawie każde pojęcie krystalizuje się „MIĘDZY” sobą a sobą - do tego stopnia, że nawet ukonstytuowanie się „ja” wymaga drogi „ja MIĘDzY ja”, a jedyny (znamienny!) wyjątek od sytuacji rozdzielania dwóch takich samych wyrazów stanowi pusta przestrzeń między „mną" a „tobą” oraz „tobą” a „mną” - czytelnik nabiera przeświadczenia, że tekst „litanii konkretnej” dlatego przywarł do krzyża, iż składające się na niego słowa docierają do własnego sensu w jednym wspólnym centralnym punkcie przecięcia wszystkiego ze wszystkim, który - wobec wyrazistych kontekstów biblijnych - nie może być pojmowany inaczej jak teologicznie. W utworze Bocian w pomysłowy sposób zostaje tym samym zaktualizowana koncentryczna czasoprzestrzeń, właściwa tradycyjnej litanii, a wynika to nie tyle z samego tekstu (czyli tego, co zostało w słowach zwerbalizowane), ile z relacji „MIĘDZY” tekstem i obrazem, w ramach odzyskiwanego synkretyzmu sztuk, komunikujących tę samą wizję rzeczywistości, zapisaną w litanijnym gatunku.

Dochodzimy w ten sposób do wniosku raczej nieoczekiwanego. Jakże często w kulturze europejskiej sztuka wizualna - inaczej niż sztuka słowa bywała podejrzewana o niedobory w planie znaczeniowym. Nikt oczywiście nie wątpił, że malarstwo coś znaczy, sensy te wydawały się jednak mniej precyzyjne niż w literaturze. Jak pamiętamy z klasycznej pracy Émile’a Benveniste’a, tylko w wypadku języka można stwierdzić „posiadanie jednocześnie znaczeniowości znaków i znaczeniowości wypowiedzenia” (Benveniste 1977: 34). Sytuacja okazuje się jednak diametralnie zmieniać, gdy sztuka obrazu odzyskuje synkretyczny związek ze sztuką słowa. Obraz nie tylko otrzymuje wówczas możliwość „przemawiania”, tak jakby dysponował jednak warstwą „Znaczeniowości znaków”, lecz jest także w stanie wydusić niejako z tekstu taką warstwę sensu, której w samym tylko języku - pomimo jego „podwójnej znaczeniowości” (Benveniste 1977: 33) - nie dało się jasno wypowiedzieć. Zjawisko z gruntu poetyckie, jakim jest gatunek - w tym wypadku: litania nie odsłaniało czytelnie swoich zasobów znaczeniowych tak długo, jak długo byliśmy ograniczeni do tekstu językowego. Włączenie aspektów kompozycji plastycznej sprawiło, że wszystkie interpretacyjne wątpliwości nas opuściły, a semantyka gatunku stanęła otworem. 
Możemy dzięki temu udzielić precyzyjnej odpowiedzi na pytanie, w jakim stopniu gatunkowy obraz świata litanii aktualizuje się u poetów niemieckojęzycznych: Gomringera i Jandla, w jakim zaś stopniu ujawnia się w dramacie Bocian.

U dwóch pierwszych autorów bywa on albo zupełnie nierozpoznawalny, albo w jakiś sposób odległy. Gdy jest nierozpoznawalny, wówczas wspierający litanię wizualny komponent przypomina sytuację skojarzenia w słowniku obrazkowym któregoś z leksemów z niewłaściwą ilustracją. Utraciwszy wiedzę na temat przynależnego gatunkowi podłoża semantycznego, rozpaczliwie próbujemy je odzyskać, generując fałszywe ikoniczne przedstawienia, dokumentujące tylko naszą bezradność. Gdy z kolei gatunkowy obraz świata jest traktowany jako coś odległego, wówczas ilustracja zgadza się wprawdzie w wyrazem, sam jednak wyraz zostaje wyizolowany z własnej mowy i przypisany do języka obcego. Można ten język zrozumieć, ale niełatwo się w nim odnaleźć. Jedynie dramat Bocian pozwala mówić o uniknięciu lub przezwyciężeniu obu tych problemów: komponent wizualny naświetla właściwą gatunkowi czasoprzestrzeń tekstu, tekst zaś wchodzi w semantyczną interferencję z ujawnionym wizualnie obrazem świata.

Wnioski te stają się zaś istotne nie tyle w odniesieniu do omówionych w tym artykule utworów, ile w kontekście rozważań porównawczych nad sytuacją litanii w niemieckojęzycznej i polskiej poezji konkretnej. Mogłoby się teoretycznie wydawać, że permutacyjna technika kreowania tekstu, właściwa tej twórczości, nieomal z zasady powinna nie tylko przejmować wszelkie wzorce, jakie wypracowała przez tysiąclecia tradycja litanii, lecz także wchłonąć towarzyszący im przez wieki obraz świata. Ktoś mógłby nawet powiedzieć, że permutacje konkretystów, operujące wariantami inwariantu, zakładają podobny system stosunków między jednostkami dzieła jak w litanijnej czasoprzestrzeni z jej pojedynczym stwarzającym źródłem i nieskończoną różnorodnością stworzeń. Kłopot w tym, że poezja konkretna rzadko kiedy daje możliwość jednoznacznego potwierdzenia tych interpretacyjnych domniemań. Wprawdzie bardzo chętnie łączy sztukę słowa ze sztuką obrazu, jest jednak przeważnie zbyt lapidarna, by można było zmierzyć, w jakim stopniu przenika ją gatunkowy obraz świata litanii.

Na tym tle utwory omówione w tym artykule wydają się ważnymi i znaczącymi wyjątkami. Wskazują na daleko idącą rozbieżność w dostępie do litanijnej tradycji u poetów z różnych krajów, czego nie da się wyjaśnić tak po prostu odmienną dynamiką sekularyzacji w Polsce i na Zachodzie`. Wbrew

7 Zwłaszcza w kontekście prac podejmujących temat religijnych tonów w twórczości Jandla (Gellner 2009: 105-118; Schwens-Harrant 2015: 359-360). 
pozorom, stanowiska konkretystów niemieckojęzycznych nie tłumaczy na przykład niska ranga litanii w pobożności protestanckiej. Trudno byłoby tak twierdzić zarówno w stosunku do Jandla, urodzonego w katolickiej Austrii, jak i Gomringera, wprawdzie przez długi czas żyjącego w Niemczech, lecz urodzonego w katolickiej Boliwii, a kształcącego się w Szwajcarii i Rzymie. Postawy Jandla nie wyjaśnia również - skądinąd trafna - teza Brigitte Schwens-Harrant, że wiedeński poeta „nie rozmontowuje Boga, lecz interesuje go słowo Bóg” (Schwens-Harrant 2015: 360). Wydaje się bowiem, że słowo „Bóg” samo w sobie nie jest w tej twórczości problemem. Właściwy problem rodzi się dopiero $\mathrm{z}$ braku poczucia zadomowienia $\mathrm{w}$ gatunku pozwalającym to imię wypowiedzieć z przekonaniem, że się je naprawdę wypowiada. Jeżeli więc rację ma Bernahard Fetz, że dla tej twórczości „tematem nie są ani zaświaty, ani Bóg, lecz możliwość postrzegania zaświatów i Boga” (cyt. za: Schwens-Harrant 2015: 360), to warto przypomnieć, że litanijna czasoprzestrzeń zawsze była niczym innym jak właśnie formą postrzegania. Czy stało się ono niedostępne lub zgoła niewykonalne dlatego, iż eksponująca je sztuka obrazu tak dalece w ciągu wieków oddaliła się od sztuki nazywania (sztuki słowa), że nie sposób ich ze sobą połączyć mostem przekładu, tłumacząc jedną na drugą - nawet jeżeli zdają się współwystępować w jednym i tym samym dziele? I czy sugerowana w tym pytaniu konstatacja na temat rozejścia się zespolonych kiedyś dziedzin artystycznych ma się odnosić jedynie do niemieckojęzycznej kultury, testowanej poetyckimi eksperymentami przez Gomringera i Jandla, czy również - nieco szerzej i tym bardziej pesymistycznie - jest to diagnoza dotycząca człowieka tej kultury, u którego rozluźniły się połączenia między tym, co się mówi, a tym, co się postrzega, i w którym pękła zdolność obustronnego przechodzenia między sferą deklaracji a sferą przeświadczenia?

Jeżeli którakolwiek z tych hipotez - wyrażonych tu najostrożniej, w postaci pytań - jest prawdziwa, jakże inne wnioski trzeba nam wysnuć na temat kondycji litanii w kulturze polskiej. Bocian otwarcie protestowała przeciwko włączaniu polskiej i zachodniej poezji konkretnej w ten sam klucz interpretacyjny. W liście do Małgorzaty Dawidek-Gryglickiej stwierdziła między innymi: „zaczęto polskie dokonania opisywać albo wręcz przyklejać do teoretyzmów w Zachodu, a przez to odrzucano tę właśnie odmienność, a nas prawie traktowano jako spóźnionych [...] plagiatorów" (Dawidek-Gryglicka 2012: 243). Polska poezja konkretna kształtowała się wprawdzie w kontekście tej samej sytuacji powojennej, przeżywanej jednak od przeciwnej strony, zarówno geograficznie, jak i kulturowo, by nie powiedzieć - duchowo. Również wzorzec litanii czerpany był z inaczej rozpoznawanych źródeł. W okresie drugiej wojny światowej wyjątkowy status tego gatunku brał się po części z suplikacyjno- 
-wyzwoleńczej tradycji romantyków (Sadowski 2011: 325-326), a po części także stąd, że w krajobrazie tygodniami bombardowanych miast i kościołów litania pełniła funkcję kompensacyjną wobec braku dostępu do mszy świętej. Dlatego też „Litania konkretystyczna” Bocian nie ogranicza się do przerzucenia mostu „MIĘDZY” słowem i obrazem, nie poprzestaje na ujawnieniu teocentrycznej czasoprzestrzeni własnego gatunku i nie chce być tylko dziełem przeznaczonym do oglądania czy tekstem, który można po cichu przeczytać. „Litania konkretystyczna”, włączona w dramat, a więc wyprowadzona na scenę, ma być usłyszana, wybrzmiewając przed audytorium w swoich nieskrępowanych paraliturgicznych tonach i z tym większą pewnością demonstrując zjednoczenie sztuk, które w odległych czasach wspólnymi siłami zdefiniowały semantyczne podłoże litanijnego gatunku.

\section{| Bibliografia}

Benveniste Émile (1977), Semiologia języka, przeł. Krystyna Falicka, w: tenże, Znak, styl, konwencja, wyb. Michał Głowiński, Czytelnik, Warszawa, s. 11-42. Bohn Willard (2011), Reading Visual Poetry, Fairleigh Dickinson University Press, Lanham.

Bernstein Nils (2011), "kennen sie mich herren / meine damen und herren": Phraseologismen in Moderner Lyrik am Beispiel von Ernst Jandl und Nicanor Parra, Königshausen \& Neumann, Würzburg.

Bocian Marianna (1979), Odejście Kaina, Zakład Narodowy im. Ossolińskich, Wrocław.

Dawidek-Gryglicka Małgorzata (2012), Historia tekstu wizualnego. Polska po 1967 roku, korporacja Ha!art, Kraków-Wrocław.

Gellner Christoph (2009), „das tier mensch das tier tier der schöpfer beider sei gelobt“: Ernst Jandls radikale religiöse Lyrik, w: Religion und Gegenwartsliteratur: Spielarten einer Liaison, red. Albrecht Grözinger, Andreas Mauz, Adrian Portmann, Königshausen \& Neumann, Würzburg, s. 105-117.

Gomringer Eugen (1975), jede sieht es sanders..., karta noworoczna dla przyjaciół, NOWEA, Düsseldorf.

Gomringer Eugen (1977), konstellationen - ideaogramme - stundenbuch, Philipp Reclam jun., Stuttgart.

Higgins Dick (1987), Pattern Poetry: Guide to an Unknown Literature, State University of New York Press, New York.

Jandl Ernst (1997), poetische werke, t. 1-10, red. Klaus Siblewski, Luchterhand, München. 
Jandl Ernst (1979), Die poetische Syntax in den Gedichten von Friederike Mayröcker, „Modern Austrian Literature”, t. 12, nr 3/4, s. 237-265.

Jandl Ernst (2008), Ottos Mops hopst, il. Erhard Dietl, cbj, München.

Kremer Aleksandra (2015), Przypadki poezji konkretnej, Instytut Badań Literackich PAN, Warszawa.

Sadowski Witold (2018), Europejski wiersz litanijny. W innej czasoprzestrzeni, Wydawnictwa Uniwersytetu Warszawskiego, Warszawa.

Sadowski Witold (2011), Litania i poezja. Na materiale literatury polskiej od XI do XXI wieku, Wydawnictwa Uniwersytetu Warszawskiego, Warszawa.

Sadowski Witold (2016), Wiersz litanijny w przekładzie na obraz, w: Ikonoklazm i ikonofilia: Między historiq a wspótczesnością, red. Agata Stankowska, Marcin Telicki, Poznańskie Towarzystwo Przyjaciół Nauk, Poznań, s. 61-72.

Sadowski Witold, Kowalska Magdalena, Kubas Magdalena Maria (2020), Studies on Litanies in the Past and Present, w: The Litany in Arts and Cultures, red. Witold Sadowski, Francesco Marsciani, Brepols Publishers, Turnhout, s. 1-24.

Schwens-Harrant Brigitte (2015), Literatur als Litanei, w: Religion und Literatur im 20. und 21. Jahrhundert: Motive, Sprechweisen, Medien, red. Tim Lörke, Robert Walter-Jochum, V\&R unipress, Göttingen, s. 353-366.

Sławek Tadeusz (1989), Między literami. Szkice o poezji konkretnej, Wydawnictwo Dolnośląskie, Wrocław.

Sławek Tadeusz (2007), Przed-teo, za-logia. Stanisława Dróżdża teologia przyimków, „Anthropos”, nr 8-9, https://tinyurl.com/58u5y9u4 [dostęp: 01.09.2020].

Toury Gideon (1986), Translation: A Cultural-Semiotic Perspective, w: Encyclopedic Dictionary of Semiotics, t. 2, red. Thomas A. Sebeok, Mouton de Gruyter, Berlin, s. 1111-1124.

Wiesiołowski Aleksandr (1913), Tri glawy iz istoriczeskoj poetiki, w: tenże, Sobranie soczinienij, t. 1, Tipografija Imperatorskoj Akademii Nauk, Sankt-

-Petersburg, s. 226-481.

\section{| Abstrakt}

\section{Witold SADOWSKI}

Wizualizacja litanii w poezji konkretnej: Gomringer, Jandl, Bocian

W artykule przywołane zostają dzieła poezji konkretnej w języku polskim i niemieckim, które spełniają jednocześnie dwa kryteria: 1) łączą sztukę słowa i sztukę obrazu oraz 2) ze względu na sposób operowania powtarzalnością dają się rozpatrywać jako litanie. Pada pytanie, czy w tych utworach respektowana jest ta sama 
wizja czasoprzestrzeni, jaka obowiązywała w litaniach średniowiecznych. Analiza relacji intersemiotycznych między językowym i wizualnym aspektem badanych dzieł wskazuje na zasadniczą różnicę między polską i niemieckojęzyczną poezją konkretną w zakresie dostępu do gatunkowego obrazu świata litanii.

Słowa kluczowe: litania; poezja konkretna; przekład intersemiotyczny; synkretyzm sztuk; czasoprzestrzeń

\section{| Abstract}

\section{WitOLD SADOWSKI}

\section{Visualisation of the Litany in Concrete Poetry: Gomringer, Jandl, Bocian}

The article presents examples of concrete poetry in Polish and German, examples that simultaneously meet the two following criteria: 1) they combine both literary and visual elements, and 2) can be considered as litanies because of the pattern of repetition used. A question is posed as to whether the poems are based on the same concept of space-time as in the medieval litanies. As the analysis shows, inter-semiotic relations between the linguistic and the visual aspects of the poems are indicative of a substantial divergence between Polish and German-language concrete poetry as regards their access to the generic worldview of the litany.

Keywords: litany; concrete poetry; inter-semiotic translation; syncretism of arts; space-time

\section{| Nota o autorze}

Witold Sadowski - prof., literaturoznawca, pracownik naukowy Wydziału Polonistyki Uniwersytetu Warszawskiego, autor publikacji na temat historii i teorii wiersza, genologii, związków między literaturą a sztukami plastycznymi, twórczości poetów polskich (współczesnych i dawniejszych) oraz form religijnych w poezji europejskiej. Opublikował między innymi książki: Europejski wiersz litanijny. W innej czasoprzestrzeni (2018), Litania i poezja. Na materiale literatury polskiej od XI do XXI wieku (2011), Wiersz wolny jako tekst graficzny (2004), Tekst graficzny Białoszewskiego (1999).

E-mail: sadowski@uw.edu.pl

ORCID: 0000-0002-9816-0111 
